\title{
MADU UNTUK LUKA PASIEN DIABETIC FOOT ULCER (DFU): LITERATURE REVIEW
}

\author{
Qiantara Putra $^{1}$, Yusrini ${ }^{2}$, Ashar Prima ${ }^{3 *}$ \\ ${ }^{1}$ Prodi Keperawatan D3, Jurusan Keperawatan, Sekolah Tinggi Ilmu Kesehatan Bani Saleh \\ ${ }^{2}$ Departemen Keperawatan Jiwa, Jurusan Keperawatan, Sekolah Tinggi Ilmu Kesehatan Bani \\ saleh, Bekasi, Indonesia \\ ${ }^{3 *}$ Departemen Keperawatan Medikal Bedah, Jurusan Keperawatan, Sekolah Tinggi Ilmu \\ Kesehatan Bani Saleh, Bekasi, Indonesia \\ E-mail: ${ }^{1}$ nasyuriqiantara@ gmail.com, ${ }^{2}$ yusrini@ @tikesbanisaleh.ac.id, \\ 3*ashar@stikesbanisaleh.ac.id \\ *Corresponding Author
}

\begin{abstract}
Abstrak
Tujuan: Tujuan penelitian ini adalah mengetahui efektifitas penggunaan madu sebagai dressing dalam penyembuhan luka pada pasien DFU berdasarkan literatur. Metode: Karya tulis ilmiah ini merupakan studi literatur pencarian menggunakan database elektronik google Schoolar, semantik Schoolar, dan PubMed. Kata kunci yang digunakan dalam pencarian adalah Diabetic Foot Ulcer atau Ulkus Kaki Diabetik, Honey atau Madu, Wound Healing atau Penyembuhan Luka. Kriteria inklusi yang digunakan dalam artikel dapat diakses, naskah full text, dalam bahasa Inggris dan bahasa Indonesia, gratis, tahun jurnal yang digunakan dibatasi 10 tahun terakhir. Hasil: ditemukan masing-masing 1 Pubmed, 2 google Schoolar, dari 3 artikel membahas penggunaan madu untuk penyembuhan luka pada pasien ulkus kaki diabetik. Hasil: Hasil studi literatur menunjukkan bahwa 3 artikel melaporkan bahwa madu dapat mempercepat penyembuhan luka pada pasien ulkus kaki diabetik karena madu dapat merangsang pertumbuhan granulasi, bersifat antibakteri, dan melembabkan luka. Kesimpulan: Tiga artikel menyatakan bahwa pemberian madu memiliki efektifitas terhadap penyembuhan luka pada pasien ulkus kaki diabetik.
\end{abstract}

Kata Kunci: Kaki Diabetik, Madu Penyembuhan Luka

\begin{abstract}
Objective:The purpose of this study was to determined the effectiveness of the use of honey for wound healing in diabetic foot ulcer patients based on a literature search Methods: This scientific paper was a search literature study using an electronic database google scholar, semantic scholar, and pubmed. The keywords used in the search were Diabetic Foot Ulcer or Diabetik Ulkus Pada Kaki, Honey or Madu, Wound healing or Penyembuhan Luka. The inclusion criteria used in the article are accessible, full text manuscript, in English and Indonesian, free of charge, the journal year used is limited to the last 10 years, the results are found
\end{abstract}


each 1 pubmed, 2 google scholar, from 3 articles discussing the use of huney for wound healing in diabetic foot ulcer patients.Results: The results of the literature study showed that the 3 articles reported that honey can accelerate wound healing in diabetic foot ulcer patients because honey can stimulate granulation growth, be antibacterial, and moisturize wounds.Conclusion: Based on the results of the literature study, it can be concluded that from 3 articles stated that the administration of honey has an effectiveness on wound healing in diabetic foot ulcer patients.

Keywords: Diabetic Foot Ulcer, Honey, Wound Healin

\section{Pendahuluan}

Penyakit diabetes merupakan kondisi jangka panjang yang serius yang berdampak besar pada kehidupan dan kesejahteraan individu, keluarga, dan masyarakat di seluruh dunia. Penyakit diabetes adalah salah satu dari 10 penyebab kematian teratas pada orang dewasa, dan diperkirakan telah menyebabkan empat juta kematian secara global pada diabetes 2017 (Saeedi et al., 2019).

Salah satu jenis komplikasi yang dapat dialami oleh pasien Diabetes adalah Diabetic Foot Ulcer (DFU). Diabetic Foot Ulcer (DFU) adalah komplikasi kronik dari Diabetes Melitus yang terjadi pada tungkai bawah, biasanya berupa lesi pada jaringan yang terkait dengan gangguan neurologis dan penyakit pembuluh darah perifer yang disebabkan oleh beberapa faktor (Kusumaningrumetal.,2020). Diabetic Foot Ulcer (DFU) dapat mempengaruhi kualitas hidup dengan memperburuk aspek fisik, sosial, psikologis dan keuangan kesehatan (Sekhar et al., 2015). Diabetic foot ulcer (DFU) juga merupakan salah satu komplikasi yang terparah dari dibetes melitus karena sebagian besar berkaitan dengan amputasi dan kecacatan individu yang diakibatkan. Diperkirakan $70 \%$ dari amputasi nontraumatic yang dilakukan di rumah sakit dunia pertama disebabkan oleh kaki diabetes. Selain itu diperkirakan bahwa $15 \%$ penderita diabetes sepanjang hidupnya mereka mengalami lesi kaki, yang prognosisnya dipengaruhi oleh penyakit pembuluh darah dan infeksi, yang merupakan komplikasi terkait di lebih dari 50\% amputasi tungkai bawah (García-Morales et al., 2011).

Penggunaan dressing pada perawatan luka Diabetic Foot Ulcer (DFU), sangat bervariasi, misalnya penggunaan modern dressing dan pemanfaatan bahan alam sebagai dressing. Contoh dressing dengan pemanfaatan bahan alam adalah madu, lidah buaya, minyak kelapa, dan minyak zaitun. Madu merupakan bahan alami yang diproduksi oleh berbagai spesies lebah madu di dunia. Produk yang dihasilkan dari pengumpulan dan pengolahan nektar oleh lebah dari tumbuhan di sekitarnya adalah larutan kental padat yang terdiri dari gula dan protein, enzim, dan asam amino. Madu terdiri dari enzim termasuk air, sukrosa, glukosa, fruktosa, asam amino, lilin lebah, serbuk sari, pigmen, mineral dan glukosa oksidase yang mengubah sukrosa menjadi glukosa dan fruktosa sederhana dan menghasilkan asam glukonat (Yilmaz \& Aygin, 2020). Madu mempunyai beberapa manfaat penting dalam proses penyembuhan luka seperti aktivitas anti inflamasi, aktivitas antibakterial, aktivitas antioksidan, kemampuan menstimulasi proses 
pengangkatan jaringan mati/ debridement, mengurangi bau pada luka, serta tetap mempertahankan kelembapan luka yang pada akhirnya dapat membantu mempercepat penyembuhan luka (Gunawan, 2017).

Penyakit diabetes ditemukan pada setiap populasi di dunia dan di semua wilayah, termasuk pedesaan di negara berpenghasilan rendah dan menengah. Jumlah penderita diabetes terus meningkat, dengan perkiraan WHO tahun 2018 ada 422 juta orang dewasa dengan diabetes di seluruh dunia pada tahun 2014. Jumlah penderita diabetes di Indonesia setiap tahun meningkat (Widodo et al., 2016). Prevalensi yang disesuaikan dengan usia pada orang dewasa meningkat 4,7\% pada tahun 1980 menjadi $8,5 \%$ pada tahun 2014, dengan peningkatan terbesar pada tingkat rendah dan negara berpenghasilan menengah dibandingkan dengan negara berpenghasilan tinggi (WHO 2019). Indonesia sendiri menunjukan bahwa prevalensi diabetes melitus berdasarkan diagnosis dokter pada umur $\geq 15$ tahun sebesar $2 \%$. Angka ini menunjukan peningkatan dibandingkan prevalensi diabetes melitus pada penduduk $\geq 15$ tahun pada hasil Riskesdas 2013 sebesar 1,5\% ('Riskesdas', 2018). Berangkat dari masalah tersebut, penelitian ini bertujuan untuk membuat literature review terkait dengan penggunaan madu untuk penyembuhan luka pada pasien Diabetic Foot Ulcer.

\section{Metode}

\section{Formulasi PICO}

Pendekatan yang digunakan dalam penelitian yaitu dengan literature review. Pecarian artikel dilakukan dengan menggunakan Formulasi PICO (Population, intervention, Comparation and Outcomes). PICO dijabarkan sebagai berikut:

Population : Pasien Diabetic Foot Ulcer (DFU).

Intervention : Madu.

Comparation :-

Outcome : Penyembuhan Luka.

\section{Kriteria Inklusi dan Eksklusi}

Kriteria Inklusi:

a. Subjek pasien Diabetic Foot Ulcer (DFU).

b. Naskah Fulltext.

c. Bahasa yang digunakan adalah Bahasa Indonesia dan Bahas Inggris.

d. Tahun terbit 10 tahun terakhir 2011-2021.

e. Sesuai dengan topik penelitian.

Kriteria Eksklusi:
a. Naskah dalam bentuk abstrak dan tidak dapat di akses
b. Artikel tidak sesuai dengan topik penelitian
c. Artikel dalam bahasa selain Bahasa Indonesia dan Bahasa Inggris

\section{Literature Search}

Pencarian artikel menggunakan search engine database yaitu Google Schoolar, Pubmed, Semantic Schoolar. Pencarian Artikel dilakukan pada bulan Mei 2021. Kata kunci menggunakan dua bahasa yaitu berbahasa Indonesia untuk database 


\section{JINTAN: Jurnal Ilmu Keperawatan}

ISSN 2774-468X (Media Online)

Vol 2, No 1, Bulan Januari 2022

Hal 14-26

Google Scholar. Kata kunci berbahasa Inggris untuk database Google Scholar, Pubmed dan Semantic Scholar. Kata kunci berbahasa Indonesia yaitu "Pasien diabetik ulkus pada kaki" DAN "Madu" DAN "Penyembuhan Luka". Kata kunci berbahasa Inggris yaitu "Diabetic Foot Ulcer Patient" AND "Honey" AND "Wound Healing".

Hasil penelusuran didapatkan 4859 Artikel, kemudian dilakukan filterisasi dengan menggukanan kriteria yang telah ditentukan. Hasil akhir didapatkan 3 artikel, kemudian artikel-artikel ini direview oleh 2 orang menggunakan tools penilaian dari JBI critical appraisal. Artikel yang memenuhi syarat yaitu memiliki poin $>50 \%$ akan dijadikan sebagai artikel yang eligible untuk direview. Alur Pencaharian sebagai berikut:

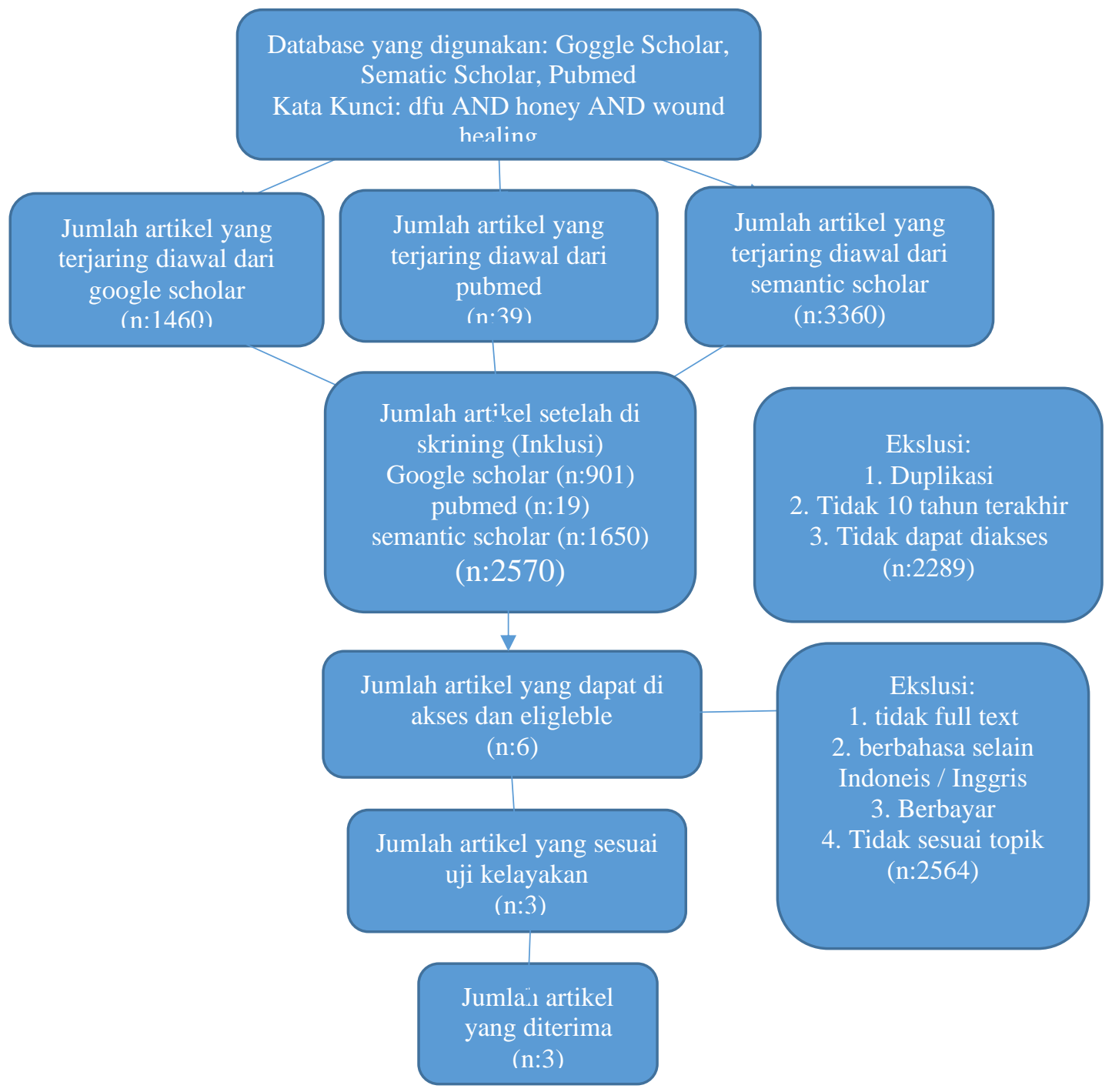

Gambar 1. Diagram Flow Pencarian Studi 


\section{JINTAN: Jurnal Ilmu Keperawatan}

ISSN 2774-468X (Media Online)

Vol 2, No 1, Bulan Januari 2022

Hal 14-26

\section{Hasil Penelitian}

Tabel 1. Daftar Pencarian Literatur

\begin{tabular}{|c|c|c|c|c|c|c|c|}
\hline No & $\begin{array}{c}\text { Judul/Nama Penulis, } \\
\text { Author } \\
\text { Tahun }\end{array}$ & Nama Jurnal & $\begin{array}{c}\text { Tujuan } \\
\text { Penelitian }\end{array}$ & Populasi dan Sample & Jenis Penelitian & $\begin{array}{c}\text { Metode } \\
\text { Pengumpulan } \\
\text { data }\end{array}$ & Temuan Penting \\
\hline 1. & $\begin{array}{l}\text { A Pilot Randomized, } \\
\text { Controlled Study of } \\
\text { Nanocrystalline Silver, } \\
\text { Manuka Honey, and } \\
\text { Conventional } \\
\text { Dressing in Healing } \\
\text { Diabetic Foot Ulcer } \\
\text { (Ka-Kit Tsang,Enid Wai- } \\
\text { Yung Kwong,Tony Shing- } \\
\text { Shun To,Joanne Wai-Yee } \\
\text { Chung,and Thomas } \\
\text { Kwok-Shing Wong). } \\
\text { (2017). }\end{array}$ & $\begin{array}{l}\text { Evidence-Based } \\
\text { Complementary } \\
\text { and Alternative } \\
\text { Medicine }\end{array}$ & $\begin{array}{l}\text { Penelitian ini } \\
\text { bertujuan untuk } \\
\text { menyelidiki } \\
\text { efektivitas nAg } \\
\text { terhadap MH } \\
\text { dan balutan } \\
\text { konvensional } \\
\text { dalam } \\
\text { penyembuhan } \\
\text { DFU }\end{array}$ & $\begin{array}{l}\text { Populasi ini diambil } \\
\text { dari } 2 \text { rumah sakit } \\
\text { regional dan satu klinik } \\
\text { rawat jalan umum. } \\
\text { Kriteria inklusi } \\
\text { termasuk subjek yang } \\
\text { tinggal di lingkungan } \\
\text { komunitas, menjadi } \\
\text { pasien DM tipe 2, usia } \\
40 \text { atau lebih dengan } \\
\text { DFU di bawah } \\
\text { malleolar, ukuran luka } \\
\text { lebih besar dari } \\
\text { diameter 1cm, dan tidak } \\
\text { ada operasi yang dapat } \\
\text { diperkirakan dalam } \\
\text { studi } 12 \text { minggu. }\end{array}$ & $\begin{array}{l}\text { In this open- } \\
\text { label prospective } \\
\text { pilot randomized } \\
\text { control }\end{array}$ & $\begin{array}{l}\text { Pemberian madu } \\
\text { dilakukan } \\
\text { selama } 12 \\
\text { minggu, outcame } \\
\text { yang ukur terdiri } \\
\text { dari } \\
\text { penyembuhan } \\
\text { luka, pengukuran } \\
\text { luka DFU, tanda } \\
\text { klinis luka, } \\
\text { bakteri pada } \\
\text { luka, infeksi } \\
\text { pada luka selama } \\
\text { 12 minggu. } \\
\text { 1. penyembuhan } \\
\text { luka dinilai oleh } \\
\text { asisten peneliti } \\
\text { B, yang } \\
\text { merupakan } \\
\text { perawat terdaftar } \\
\text { berpengalaman, } \\
\text { disetiap } \\
\text { kunjungan } \\
\text { klinik. } \\
\text { 2. pengukuran } \\
\text { luka dilakukan } \\
\text { dengan cara } \\
\text { visitrak digital. } \\
\text { 3. bakteri. Kultur } \\
\text { jaringan }\end{array}$ & $\begin{array}{l}\text { Dalam penelitian } \\
\text { ini, karakteristik } \\
\text { dasar dapat } \\
\text { dibandingkan } \\
\text { antara kelompok. } \\
\text { 1.Madu hanuka } \\
\text { dapat } \\
\text { mengurangi } \\
\text { infeksi. } \\
\text { 2. Madu hanuka } \\
\text { dapat } \\
\text { melembabkan } \\
\text { luka. } \\
\text { 3.Madu hanuka } \\
\text { dapat } \\
\text { mempercepat } \\
\text { granulasi. }\end{array}$ \\
\hline
\end{tabular}




\section{JINTAN: Jurnal Ilmu Keperawatan}

ISSN 2774-468X (Media Online)

Vol 2, No 1, Bulan Januari 2022

Hal 14-26

\begin{tabular}{|c|c|c|c|c|c|c|c|}
\hline & & & & & & $\begin{array}{l}\text { kuantitatif } \\
\text { digunakan } \\
\text { sebagai alat } \\
\text { untuk } \\
\text { menentukan } \\
\text { beban biologis } \\
\text { luka. }\end{array}$ & \\
\hline 2. & $\begin{array}{l}\text { Effectiveness of using } \\
\text { sialang honey on wound } \\
\text { bed preparation in } \\
\text { diabetic foot ulcer } \\
\text { (sukhri Herianto Ritonga, } \\
\text { Nanda Masraini Daulay). } \\
\text { (2019). }\end{array}$ & $\begin{array}{l}\text { Enfermeria } \\
\text { Clsinica }\end{array}$ & $\begin{array}{l}\text { Tujuan } \\
\text { penelitian ini } \\
\text { untuk } \\
\text { mengetahui } \\
\text { efektivitas madu } \\
\text { sialang pada } \\
\text { persiapan luka } \\
\text { pada pasien DFU }\end{array}$ & $\begin{array}{l}\text { Populasi dalam } \\
\text { penelitian ini adalah } \\
\text { seluruh penderita DFU } \\
\text { di kota Padang } \\
\text { sidimpuan. Teknik } \\
\text { pengambilan sampel } \\
\text { yang digunakan adalah } \\
\text { consecutive sampling } \\
\text { dimana semua } \\
\text { penderita DFU dapat } \\
\text { menjadi sampel } \\
\text { penelitian jika } \\
\text { memenuhi kriteria yang } \\
\text { ada dan perolehannya } \\
\text { dalam batas waktu yang } \\
\text { ditentukan. }\end{array}$ & $\begin{array}{l}\text { The study design } \\
\text { was quasy } \\
\text { experiment }\end{array}$ & $\begin{array}{l}\text { Instrumen yang } \\
\text { digunakan dalam } \\
\text { penelitian ini } \\
\text { adalah skor dasar } \\
\text { luka, dimana } \\
\text { hasil pengkuran } \\
\text { akan dianalisis } \\
\text { menggunakan uji } \\
\text { wilcoxon dengan } \\
\text { tingkat } \\
\text { kepercayaan } \\
\text { 95\%. }\end{array}$ & $\begin{array}{l}\text { 1. Mayoritas } \\
\text { responden } \\
\text { pernah } \\
\text { mengalami } \\
\text { penyakit DFU } \\
\text { selama } 1 \text { bulan } \\
\text { dengan } \\
\text { persentase } \\
62,5 \% \text {. } \\
2 . \text { Hari } \\
\text { perawatan yang } \\
\text { dibutuhkan } \\
\text { untuk } \\
\text { mengangkat } \\
\text { jaringan yang } \\
\text { mati (persiapan } \\
\text { alas luka) } \\
\text { dimulai dari hari } \\
\text { ke } 6 . \text { Namun ada } \\
\text { satu responden } \\
\text { yang hingga hari } \\
\text { ke 14 persiapan } \\
\text { bed luka belum } \\
\text { berjalan dengan } \\
\text { baik. } \\
\text { 3. setelah } \\
\text { dilakukan } \\
\text { analisis data } \\
\text { dapat } \\
\text { disimpulkan }\end{array}$ \\
\hline
\end{tabular}




\section{JINTAN: Jurnal Ilmu Keperawatan}

ISSN 2774-468X (Media Online)

Vol 2, No 1, Bulan Januari 2022

Hal 14-26

\begin{tabular}{|c|c|c|c|c|c|c|c|}
\hline & & & & & & & $\begin{array}{l}\text { bahwa madu } \\
\text { sialang efekif } \\
\text { dalam } \\
\text { merangsang } \\
\text { preparasi alas } \\
\text { luka pada DFU } \\
\text { dengan nilai p } \\
0,011 \text {. } \\
\end{array}$ \\
\hline 3. & $\begin{array}{l}\text { One year randomized } \\
\text { controlled trial to } \\
\text { compare the effectiveness } \\
\text { of } \\
\text { honey dressing versus } \\
\text { povidone iodine dressing } \\
\text { for diabetic foot ulcer at } \\
\text { Dr. Prabhakar Kore } \\
\text { Hospital and MRC, } \\
\text { Belagavi. } \\
\text { (Ramesh S. Koujalagi, V. } \\
\text { M. Uppin, Soham Shah, } \\
\text { Dron Sharma). } \\
\text { (2020). }\end{array}$ & $\begin{array}{l}\text { International } \\
\text { Surgery Journal }\end{array}$ & $\begin{array}{l}\text { Tujuan } \\
\text { penelitian ini } \\
\text { adalah untuk } \\
\text { mengetahui } \\
\text { pengaruh } \\
\text { penggunaan } \\
\text { honey dressing } \\
\text { dibandingkan } \\
\text { dengan povidone } \\
\text { iodine dressing } \\
\text { terhadap } \\
\text { pengurangan } \\
\text { ukuran luka } \\
\text { DFU }\end{array}$ & $\begin{array}{l}\text { Populasi dalam } \\
\text { penelitian ini terdiri } \\
\text { dari } 64 \text { pasien diacak } \\
\text { menjadi } 32 . \text { Kriteria } \\
\text { inklusi debridemen } \\
\text { jaringan } \\
\text { pengelupasan/nonviable } \\
\text { pengurangan ukuran } \\
\text { ulkus, granulasi. }\end{array}$ & $\begin{array}{l}\text { This randomized } \\
\text { controlled trial }\end{array}$ & $\begin{array}{l}\text { Metode } \\
\text { pengumpulan } \\
\text { data dengan cara } \\
\text { mencari } 64 \\
\text { pasien diacak } \\
\text { menjadi } 32 \\
\text { kelompok yang } \\
\text { masing masing } \\
\text { menjalani } \\
\text { pembalutan } \\
\text { madu yang } \\
\text { belum diproses } \\
\text { dan kelompok } \\
\text { lainnya } \\
\text { menjalani } \\
\text { pembalutan } \\
\text { povidone iodine. }\end{array}$ & $\begin{array}{l}\text { Studi ini } \\
\text { menunjukkan } \\
\text { hasil yang lebih } \\
\text { baik dengan } \\
\text { balutan madu } \\
\text { untuk } \\
\text { mengurangi } \\
\text { ukuran luka pada } \\
\text { pasien DFU. }\end{array}$ \\
\hline
\end{tabular}


JINTAN: Jurnal Ilmu Keperawatan

ISSN 2774-468X (Media Online)

Vol 2, No 1, Bulan Januari 2022

Hal 14-26 


\section{Pembahasan}

Luka Diabetic Foot Ulcer (DFU) merupakan suatu keadaan yang sangat merugikan bagi penderitanya terlebih jika penanganannya tidak tepat bisa mengakibatkan kecacatan. Pengobatan luka Diabetic Foot Ulcer (DFU) tidak hanya menggunakan farmakologi ( medis ) melainkan juga bisa menggunakan bahan alami yang mudah didapatkan salah satunya adalah madu. Hal ini telah terbukti dari beberapa penelitian yang mengungkapkan keefektifan madu dalam penyembuhan luka Diabetic Foot Ulcer (DFU).

Hasil review dijabarkan sebagai berikut:

\section{Populasi dan Sampel}

Penelitian yang dilakukan oleh Tsang et al., (2017) penelitian ini dilakukan di dua rumah sakit dan satu klinik rawat jalan, pasien yang dilakukan dalam penelitian adalah pasien DM tipe 2 dengan rentang umur lebih dari 40 tahun dengan penyakit luka Diabetic Foot Ulcer (DFU) di bawah daerah malleolar, ukuran luka lebih dari $1 \mathrm{~cm}$, luka lebih dari 12 minggu, tidak ada operasi (Tsang et al., 2017).

Dalam penelitian lain yang dilakukan oleh Koujalagi et al., (2020) Populasi dalam penelitian total 32 pasien dianalisis diantara kelompok dressing madu, 26 peserta laki laki, sisanya 6 adalah perempuan. Teknik pengambilan sampel yang digunakan adalah Consecutive sampling dimana semua penderita luka Diabetic Foot Ulcer dapat menjadi sampel penelitian jika memenuhi kriteria yang ada dan perolehannya dalam batas waktu yang sudah ditentukan (Koujalagi et al., 2020).

Sementara dalam penelitian yang lain yang dilakukan oleh Herianto Ritonga \& Masraini Daulay (2019) penelitian ini dilakukan kepada pasien diabetes yang memakai insulin atau hiperglikemia oral dan menderita Diabetic Foot Ulcer (DFU) yang tidak sembuh, selama lebih dari 3 minggu dan untuk itu debridemen dipelukan untuk penyembuhan pasien yang terdaftar. Penelitian ini terdiri 64 pasien yang memakai insulin atau hiperglikemia oral dan menderita Diabetic Foot Ulcer (DFU) yang tidak sembuh, selama 3 minggu lebih dan untuk itu debridemen diperlukan untuk penyembuhan pasien yang dibagi menjadi dua kelompok masing masing 32 pasien dan pasien akan dibagi secara acak menjadi 2 kelompok (Herianto Ritonga \& Masraini Daulay, 2019).

Penelitian dari 3 artikel di atas terdapat perbedaan karakteristik responden karena dari penelitian yang dilakukan oleh Tsang et al., (2017) menjelaskan tentang rentang usia namun tidak menjelaskan tentang jenis kelamin, sedangkan penelitian yang dilakukan oleh Koujalagi et al., (2020) dan Herianto Ritonga \& Masraini Daulay, (2019) sama sama tidak menjelaskan tentang rentang umur dan jenis kelamin.

\section{Intervensi dan Instrumen}

Berbagai macam intervensi yang dilakukan untuk melakukan penyembuhan luka, pada penelitian yang dilakukan oleh Tsang et al., (2017), intervensi dilakukan oleh semua peserta menghadiri klinik perawat mingguan untuk 
ditindaklanjuti oleh penulis pertama dalam empat minggu pertama dan dua mingguan sampai mingguke 12 periode tindak lanjut. Ada total delapan kehadiran klinis. Mengenai strategi pembongkaran, customer made insole (CMI) diberikan kepada partisipan yang menderita Diabetic Foot Ulcer (DFU). Debridemen dilakukan oleh penulis pertama pada setiap kunjungan klinik untuk menurunkan tekanan lokal. Luka dibersihkan jaringan nonviable dan biofilm dibersihkan setiap kali oleh penulis pertama jika perlu perlu setelah mendapatkan persetujuan lisan: semua tendon dan jaringan avaskular yang terbuka juga distimulasi dengan jarum atau pisau sampai berdarah. Intervensi ini digunakan sebagai rekrutmen seluler ke area lokal untuk angiogenesis dan pembentukan granulasi. Balutan topikal kemudan diaplikasikan sesuai dengan urutan pengacakan (Tsang et al., 2017).

Sedangkan penelitian yang dilakukan Koujalagi et al., (2020) tidak menjelaskan secara detail tentang intervensi perawatan luka pada pasien Diabetic Foot Ulcer (DFU). Hanya menjelaskan tentang manfaat dari madu dan keefektifan madu terhadap luka pada pasien Diabetic Foot Ulcer (DFU) (Koujalagi et al., 2020).

Selanjutnya intervensi yang dilakukan oleh Herianto Ritonga \& Masraini Daulay, (2019) dengan cara semua pasien menjalani debridemen luka. Antibiotik empiris seftriakson dan metronidazol dimulai dan diubah menjadi antibiotik sensitif setelah kultur dan laporan sensitivitas. Untuk kelompok A pembalut madu dilakukan dan untuk kelompok B pembalut povidone iodine dilakukan. Pembalut dilakukan dengan teknik yang sama pembersihan dan aplikasi madu / povidone iodine dan pembalut. Sebelum aplikasi, lesi dibersihkan dari puing puing dan bahan yang tercerna dengan menggosok lembut menggunkan kain kasa dengan larutan garam normal. Madu yang belum diolah dioleskan pada kain kassa steril, yang kemudian dioleskan ke luka dan diamankan dengan benar. Kain kassa yang dibasahi povidone iodine disimpan di luka dan balutan diamankan. Pembalut luka akan diganti setiap hari selama 6 minggu masa tindak lanjut atau sampai penyembuhan total. Jika ada peredaman atau keluarnya pembalut akan diganti setiap hari dengan povidone iodine dan madu yang belum diolah. Status penyembuhan luka dipantau pada hari yang berbeda dalam selang waktu 2 minggu. Antibiotik yang sama akan digunakan pada kedua kelomok untuk membandingkan status luka yang tepat pada kedua kelompok, tidak ada perbedaan status luka dengan penggunaan antibiotik yang berbeda pada kedua kelompok (Herianto Ritonga \& Masraini Daulay, 2019).

\section{Efektivitas Pemberian Dressing Madu Pada Pasien Diabetic Foot Ulcer (DFU)}

Kefektifan penyembuhan luka Diabetic Foot Ulcer (DFU) telah terbukti dari penelitian yang dilakukan oleh Tsang et al., (2017) dan Herianto Ritonga \& Masraini Daulay, (2019) bahwa madu terbukti lebih baik dalam penyembuhan luka pada pasien Diabetic Foot Ulcer (DFU) dalam hal pengurangan ukuran luka Diabetic Foot Ulcer (DFU) dari pada balutan konvensional. Pada penelitian yang dilakukan Koujalagi et al., (2020) terapi madu efektif dalam menjaga keseimbangan kelembaban luka pada pasien Diabetic Foot Ulcer (DFU) 
Dalam ketiga artikel diatas bahwa madu efektif dalam hal pengurangan ukuran pada luka Diabetic Foot Ulcer (DFU) dan madu efektif dalam menjaga keseimbangan kelembaban pada luka Diabetic Foot Ulcer (DFU). Madu memiliki sifat antimakroba yang bisa mengobati berbagai luka infeksi, madu juga memiliki zat bioaktif yang sangat bermanfaat dalam perawatan luka.

Secara fisiologis madu signifikan dapat mempercepat penyembuhan luka pada pasien Diabetic Foot Ulcer (DFU), Hal ini dikarenakan madu sangat potensial sebagai zat anti inflamasi, aktifitas anti bakteri, dan meningkatkan pelepasan growt factor, dan efek debriding madu. Selain itu, penggunaan madu juga dapat meningkatkan aliran getah bening sehingga akan mambantu menghilangkan toksin pada luka. Honey dressing sangat efektif dalam penyembuhan luka dan mempercepat waktu penyembuhan, sehingga akan menurunkan biaya perawatan pasien (Prima et al., 2017).

\section{Kesimpulan Dan Saran}

Berdasarkan hasil literature review dapat disimpulkan bahwa madu terbukti efektif untuk penyembuhan luka pada pasien Diabetic Foot Ulcer (DFU), selain efektif madu dapat mempercepat pertumbuhan granulasi, mempercepat pertumbuhan epitelisasi, dan menjaga kelembaban pada luka Diabetic Foot Ulcer (DFU). Saran bagi profesi keperawatan diharapkan perawat luka Diabetic khususnya dapat mengaplikasikan dressing ini untuk penyembuhan luka pada pasien Diabetic Foot Ulcer (DFU). Saran bagi pendidikan kesehatan dapat menjadikan hasil Karya Ilmiah Studi literatur ini sebagai landasan untuk pengembangan ilmu keperawatan yang aplikatif terhadap pelaksanaan intervensi kolaborasi dalam hal penyembuhan luka Diabetic Foot Ulcer (DFU).

\section{Referensi}

Al Fady Faisol. Moh. Ns. (2015). MADU DAN LUKA DIABETIC.

Association, A. D. (2014). Diagnosis and classification of diabetes mellitus. Diabetes Care, 37(SUPPL.1), 81-90. https://doi.org/10.2337/dc14-S081

Astrid Petersmann1, 2, Dirk Müller-Wieland3, Ulrich A. Müller4, Rüdiger Landgraf5, Matthias Nauck1, 6. (2019). Definition, Classification and Diagnosis of Diabetes Mellitus * Authors Definition of Diabetes Mellitus Diagnostic Criteria of Diabetes Mellitus. 127(Suppl 1).

Bhatt, H., Saklani, S., \& Upadhayay, K. (2016). Anti-oxidant and anti-diabetic activities of ethanolic extract of Primula Denticulata Flowers. Indonesian $\begin{array}{llll}\text { Journal of } & \text { Pharmacy, }\end{array}$ https://doi.org/10.14499/indonesianjpharm27iss2pp74

García-Morales, E., Lázaro-Martínez, J. L., Martínez-Hernández, D., AragónSánchez, J., Beneit-Montesinos, J. V., \& González-Jurado, M. A. (2011). Impact of diabetic foot related complications on the health related quality of Life (HRQol) of patients - A regional study in Spain. International Journal 
of Lower Extremity Wounds, 10(1), 6-11. https://doi.org/10.1177/1534734611400257

Gunawan, N. A. (2017). Madu: Efektivitasnya untuk Perawatan Luka. 44(2), 138-142. file:///C:/Users/HP/Downloads/CPD-Madu-Efektivitasnya untuk Perawatan Luka.pdf

Herianto Ritonga, S., \& Masraini Daulay, N. (2019). Effectiveness of using sialang honey on wound bed preparation in diabetic foot ulcer. Enfermeria Clinica, 29(xx), 88-90. https://doi.org/10.1016/j.enfcli.2018.11.028

Kerner, W. (2014). Definition, Classification and Diagnosis of Diabetes Mellitus. 384-386.

Koujalagi, R. S., Uppin, V. M., Shah, S., \& Sharma, D. (2020). One year randomized controlled trial to compare the effectiveness of honey dressing versus povidone iodine dressing for diabetic foot ulcer at Dr. Prabhakar Kore Hospital and MRC, Belagavi. International Surgery Journal, 7(2), 506. https://doi.org/10.18203/2349-2902.isj20200306

Kusumaningrum, N. S. D., Saputri, A. D., Kusuma, H., \& Erawati, M. (2020). Karakteristik Diabetic Foot Ulcer (DFU) pada Individu dengan Diabetes Mellitus (DM): Studi Deskripsi - Cross Sectional. Journal of Holistic Nursing Science, 7(2), 88-98. https://doi.org/10.31603/nursing.v7i2.3074

Lomban, A., Kalangi, S. J. R., \& Pasiak, T. F. (2020). Manfaat Olesan Madu Pada Penyembuhan Luka Kulit. Ebiomedic, 8(2), 202-208.

Monteiro-Soares, M., Boyko, E. J., Jeffcoate, W., Mills, J. L., Russell, D., Morbach, S., \& Game, F. (2020). Diabetic foot ulcer classifications: A critical review. Diabetes/Metabolism Research and Reviews, 36(S1), 1-16. https://doi.org/10.1002/dmrr.3272

Nugroho, S. (2015). Pencegahan Dan Pengendalian Diabetes Melitus Melalui Olahraga. Medikora, IX(1). https://doi.org/10.21831/medikora.v0i1.4640

Prima, A., Andas, A. M., Ilyas, A. S., Bekasi, K., Barat, J., \& Selatan, S. (2017). COMPLEMENTARY ALTERNATIVE MEDICINE ( CAM ) TO PROMOTE WOUND HEALING IN DIABETIC ULCERS PATIENT: A LITERATURE REVIEW.

Riskesdas, Kemenkes. 2018. “InfoDATIN Pusat Data Dan Informasi Kementerian Kesehatan RI: Penyakit Diabetes militus.” (2018).

Saeedi, P., Petersohn, I., Salpea, P., Malanda, B., Karuranga, S., Unwin, N., Colagiuri, S., Guariguata, L., Motala, A. A., Ogurtsova, K., Shaw, J. E., Bright, D., \& Williams, R. (2019). Global and regional diabetes prevalence estimates for 2019 and projections for 2030 and 2045: Results from the International Diabetes Federation Diabetes Atlas, 9th edition. Diabetes Research and Clinical Practice, 157(January), 107843. https://doi.org/10.1016/j.diabres.2019.107843

Sataloff, R. T., Johns, M. M., \& Kost, K. M. (2019). DIABETES MELITUS TIPE 2.

Sekhar, M. S., Thomas, R. R., Unnikrishnan, M. K., Vijayanarayana, K., \& Rodrigues, G. S. (2015). Impact of diabetic foot ulcer on health-related quality of life: A cross-sectional study. Seminars in Vascular Surgery, 28(34), 165-171. https://doi.org/10.1053/j.semvascsurg.2015.12.001 
Sriwiyati, L., \& Kristanto, B. (2020). Karakteristik Luka Dan Penggunaan Balutan Luka Modern. Adi Husada Nursing Journal, 6(1), 8. https://doi.org/10.37036/ahnj.v6i1.161

Tsang, K. K., Kwong, E. W. Y., To, T. S. S., Chung, J. W. Y., \& Wong, T. K. S. (2017). A Pilot Randomized, Controlled Study of Nanocrystalline Silver, Manuka Honey, and Conventional Dressing in Healing Diabetic Foot Ulcer. Evidence-Based Complementary and Alternative Medicine, 2017. https://doi.org/10.1155/2017/5294890

Widodo, T. R., Susilo, C., \& Kurniawan, H. (2016). Pengaruh Terapi Ozone Bagging terhadap Penyembuhan Luka pada Pasien Ulkus Diabetikum di Rumah Luka Nirmala Kecamatan Puger Kabupaten Jember. Journal of Undergraduate Thesis, $1-8$.

Windasari, N. N. (2014). Pendidikan Kesehatan Dalam Meningkatkan Kepatuhan Merawat Kaki pada Pasien Diabetes Melitus Tipe II. Pendidikan Kesehatan Dalam Meningkatkan Kepatuhan Merawat Kaki Pada Pasien Diabetes Mellitus Tipe II, 2(1), 1-5.

world health organitation. (2019). Classification of diabetes mellitus. In Clinics in Laboratory Medicine (Vol. 21, Issue 1). https://doi.org/10.5005/jp/books/12855_84

Yilmaz, A. C., \& Aygin, D. (2020). Honey Dressing in Wound Treatment: a Systematic Review. Complementary Therapies in Medicine, 51(April 2020), 102388. https://doi.org/10.1016/j.ctim.2020.102388 